Please do not remove this page

RMIT

UNIVERSITY

\title{
The determinants of economic growth versus genuine progress in South Korea
}

Feeny, Simon; Mitchell, Heather; Tran, Christine; Clarke, Matthew

https://researchrepository.rmit.edu.au/esploro/outputs/9921859268901341/filesAndLinks?institution=61RMIT_INST\&index=null

Feeny, S., Mitchell, H., Tran, C., \& Clarke, M. (2012). The determinants of economic growth versus genuine progress in South Korea. Social Indicators Research: An International and Interdisciplinary Journal for Quality-of-Life Measurement, online, 1-20. https://doi.org/10.1007/s11205-012-0127-4

Document Version: Accepted Manuscript

Published Version: https://doi.org/10.1007/s11205-012-0127-4

Repository homepage: https://researchrepository.rmit.edu.au

(C) 2012 Springer Science+Business Media B.V.

Downloaded On 2023/04/26 10:01:50 +1000

Please do not remove this page 
Thank you for downloading this document from the RMIT Research Repository.

The RMIT Research Repository is an open access database showcasing the research outputs of RMIT University researchers.

RMIT Research Repository: http://researchbank.rmit.edu.au/

\section{Citation:}

Feeny, S, Mitchell, H, Tran, C and Clarke, M 2012, 'The determinants of economic growth versus genuine progress in South Korea', Social Indicators Research: an international and interdisciplinary journal for quality-of-life measurement, pp. 1-20.

See this record in the RMIT Research Repository at:

http://researchbank.rmit.edu.au/view/rmit:20304

Version: Accepted Manuscript

Copyright Statement: (C) 2012 Springer Science+Business Media B.V.

Link to Published Version:

http://dx.doi.org/10.1007/s11205-012-0127-4 
The Determinants of Economic Growth versus Genuine Progress in South Korea 


\section{The Determinants of Economic Growth versus Genuine Progress in South}

\section{Korea}

\section{Introduction}

Recently, there has been a renewed and strong interest in moving beyond the reliance on using Gross Domestic Product (GDP) per capita as a measure of progress. The 2009 Report of the Commission on the Measurement of Economic Performance and Social Progress, led by Nobel Prize winner Joseph Stiglitz, highlighted the limitations of GDP per capita as an indicator of economic performance and social progress. The report argued that the conventional measurement system of economic activity needs to shift away from measuring economic production and focus instead on measuring human well-being. Moreover, President of France, Nicolas Sarkozy, argued that, "For years statistics have registered an increasingly strong economic growth as a victory over shortage, until it emerged that this growth was destroying more than it was creating. The [2008 global financial] crisis doesn't only make us free to imagine other models, another future, another world. It obliges us to do so" (The Guardian, 2009). ${ }^{1}$

A number of alternative measures of progress have been devised, including the Measure of Economic Welfare (MEW) (Nordhaus and Tobin, 1973), the Index of Sustainable Economic Welfare (ISEW) 2 (Daly and Cobb 1990), and the Genuine Progress Indicator (Lawn 2003). All of these progress indices are designed to better reflect the economic welfare that is associated with

\footnotetext{
1 The shortcomings of GDP per capita as a measure of progress have long been known (Küznets, 1941; Abramavitz, 1961). For example, GDP per capita ignores non-market production and fails to account for the social and environmental costs of production. It also fails to capture the distribution of income and excludes the value of leisure and illegal activities.

${ }^{2}$ Like the GPI, the MEW was an adjusted GDP to take into account certain aspects of welfare that the GDP faled to properly consider. The ISEW was also an adjusted GDP but was more comprehensive in the adjustments made than the MEW. The ISEW is the basis of the GPI.
} 
economic activity, and incorporate sustainability components to account for resource depletion and pollution costs.

Despite the existence of these alternatives, GDP per capita remains the dominant measure of living standards. For example, the Commission on Growth and Development stressed the importance of economic growth as a means to achieve poverty reduction (World Bank, 2008). Further, the Seoul Development Consensus emanating from the 2010 G20-Seoul Summit argues for countries to be economic growth-oriented to assist with progress towards the United Nations Millennium Development Goals (MDGs), although growth should be strong, sustainable and balanced (G20, 2010).

Debates over the most appropriate measures of progress continue. What is important in this debate is whether the determinants (and, therefore, government policies and reforms) differ across progress measures. For example, are the policies that spur economic growth also effective at spurring genuine progress? Genuine progress can be considered 'good change' (Kingsbury et al. 2010). Such good change brings about positive improvements in all spheres of people's livs and is not simply limited to increased income. The intrinsic goal of genuine progress is to advance human dignity, freedom, social equity and self-determination. A lack of genuine progress is characterized by social exclusion, poverty, ill-health, powerlessness, and shortened life expectancy. Genuine progress outcomes are best achieved when communities have ownership of the goals and processes of development and where there are participatory representation, transparency and accountability mechanisms. Genuine progress outcomes must also explicitly consider the importance of gender and diversity. This requires processes that appreciate existing endogenous strengths and (often) exogenous interventions and finally it requires critical analysis, mutual learning, and acceptance of its paradoxes and dilemmas. 
If economic growth and genuine progress have similar impacts, then debates over the most appropriate measure of progress are nullified. Yet the determinants of these alternative measures of progress have not been examined previously and this is the main objective of this paper. It starts by calculating a Genuine Progress Indicator (GPI) for South Korea and proceeds by estimating empirical models to examine whether the determinants of changes in GDP per capita are the same as those for changes in genuine progress (per capita). According to Lawn and Clarke (2006, pp.17), the GPI is:

'a recently established indicator specifically designed to ascertain the impact of a growing economy on sustainable well-being. Usually comprised of around twenty individual benefit and cost items, the GPI integrates the wide-ranging impacts of economic growth into a single monetary-based index. As such, the GPI includes benefits and costs of the social and environmental kind as well as those of the standard economic variety. Whilst the GPI embraces some of the national accounting values used in the computation of GDP, its calculation accounts for a number of benefits and costs that normally escape market valuation'.

South Korea is a nation that has experienced extraordinary economic growth during the last few decades. Labelled as one of the 'Asian Tigers', South Korea experienced consistently high economic growth that averaged 8.7 per cent per year from 1963 to 1996 (Kwon, 2005). During this time, social indicators also improved markedly. Since 1960, South Korea - along with other top-performing countries such as Japan, Hong Kong, Singapore, Taiwan, Indonesia, Malaysia and Thailand, recorded economic growth more than twice as high as the rest of East Asia, triple the growth in Latin America and South Asia, and five times as much as sub-Saharan Africa. 
Despite growth falling sharply following the 1997 Asian economic crisis, it quickly recovered to average around 5 per cent for the first half of the 2000 s.

The academic literature concerning South Korea, however, demonstrates a noted lack of engagement with the social and environmental aspects of the nation's growth. Davis and Gonzalez (2003) show that between 1986 and 2001, of the 1,171 Journal of Economic Literature articles based on South Korea, 30.6 per cent were papers on economic growth, compared to just 0.8 per cent of studies examining issues of health, education and welfare. This provides further motivation for the current study.

The remainder of the paper is structured as follows: Section 2 provides a review of the relevant literature about economic growth in South Korea. The strengths and weaknesses of the GPI as a measure of progress are examined in Section 3 and the calculation of the GPI for South Korea is provided in Section 4. The data and empirical approach to examining the determinants of GDP and GPI per capita are provided in Section 5. Section 6 presents and discusses the results and Section 7 concludes.

\section{Economic Growth in South Korea: A Critical Review of the Literature}

An extensive literature has empirically examined the determinants of South Korea's impressive economic growth record. Studies have typically used the econometric analysis of historical timesseries data, cointegration techniques and error correction models.

There are a number of consistent findings within this literature. Most studies from the mid-1990s conclude that human capital plays a central role in achieving economic growth in South Korea (Sengupta and Espana, 1994; Piazolo, 1995; Kang, 2006; Harvie and Pahlvani, 2007). Methods of measuring human capital vary between studies, with one way being levels of educational 
attainment, represented by the number of South Koreans who have completed secondary school education (Lee et al., 1994). Other studies use the number of secondary school and university students as a percentage of the total population (Piazolo, 1995), or calculating the average years of schooling of South Korea's labour force (Kwack and Lee, 2006). Regardless of how it is measured, though, human capital is usually found to be an important determinant of growth.

While Lee et al. (1994) find evidence to support human capital as a determinant of economic growth, they also argue that physical capital accumulation and export expansion are more important. Yuhn and Kwon (2000) confirm the importance of investment and capital accumulation for South Korea's economic growth. Other prominent drivers of South Korea's economic growth are financial liberalisation and export expansion. Kwack and Lee (2006) used a financial liberalisation index (as constructed by Chun, 2003) while Piazolo (1995) employed dummy variables to capture the various trade policies adopted by South Korea during relevant time periods. The importance of exports for growth is confirmed by Lee et al. (1994), Sengupta and Espana (1994), Piazolo (1995) and Harvie and Pahlvani (2007). In addition to these positive drivers of growth, Piazolo (1995) finds that inflation and government consumption have negative impacts.

Other important factors in explaining South Korea's GDP per capita growth include the country's capacity to quickly adapt to rapidly evolving technology, as well its ability to explore new opportunities (Kwack and Lee, 2006); the capacity of entrepreneurs and policy makers to adjust rapidly and flexibly to external shocks; and the maintenance of relatively equitable income distribution (Harvie and Lee, 2003).

Recent studies have emerged, however, that indicate South Korea's rapid growth has come at a cost, - in the form of reduced welfare and environmental degradation. Park and Shin (2005) find 
that a large number of South Koreans experienced a decline in their living conditions in recent years. Further, while Yang (2003) finds evidence of greater quality in family life, Kwon (2005) documents South Korea's divorce rate, indicating that it increased from 1.1 divorces for every 1,000 people in 1990 to 3.5 divorces for every 1,000 people in 2003. This represents one of the highest rates in the world. Joo (2003) determines that the crime rate (defined as the total number of crimes that take place per 100,000 people) in South Korea increased 3.6 times from 1,035 in 1970 to 3,697 in 1999, while Chul-Kyoo (2004) finds a steep decline in the country's environmental resources. Moreover, despite an overall increase in income in South Korea, there has been evidence of a rise in the inequality of income distribution, particularly after the 1997 financial crisis (Cheong, 2001). These developments point to the pressing need to move beyond GDP to measure the country's progress.

\section{The GPI: strengths and limitations}

The intent of the GPI (and its antecedents: the MEW and ISEW) was to provide an alternative measure of human well-being to that of the GDP per capita (see Sametz, 1968; Nordhaus and Tobin, 1973; Daly and Cobb, 1990). This alternative measure included the costs, as well as the benefits associated with economic expansion.

As with the GDP though, the GPI is not without its limitations. The GPI is a constructed number; that is, the GPI is calculated through a series of adjustments starting with personal consumption. These adjustments are based on value judgments, but while these value judgments are explicit (and more explicit than the value judgments that underpin standard national accounts, such as GDP), the final GPI estimate is dependent on a range of criteria: the analyst's arbitrary values, choices and preferences for the methodologies, as well as what costs and benefits are included or excluded from the GPI (Clarke and Islam, 2004). While the list of adjustments are becoming increasingly common across GPI studies (starting with Nordhaus and Tobin, 1973; and Daly and Cobb, 1990), most studies have slight variations (cf. Daly and Cobb, 
1990; Diefenbacher, 1994; Hamilton, 1998; Jackson and Marks, 1994; Lawn and Sanders, 1999; Rosenberg and Oegema, 1995; Stockhammer et al., 1997). Neumayer (1999) and Dietz and Neumayer (2006) argue that, without a standard set of adjustments and common methodology for the estimation of these adjustments, the construction of the GPI is subjective and lacks scientific rigour.

However, it is possible to identify a standard list of GPI indicators and consider the question of the 'ownership' of the costs and benefits associated with economic growth. Table 1 lists the most common adjustments made within a GPI.

\section{Insert Table 1}

\section{Calculating a GPI for South Korea: data and methodology}

The variables and methodology used in calculating a GPI for South Korea were largely based on that employed by Lawn and Clarke (2006). Data are from a variety of sources including the World Bank, the International Monetary Fund (IMF), the Korean Statistical Information System (KOSIS), the Korean National Statistical Office, the OECD, the Bank of Korea, the Republic of Korea Ministry of Environment, the United Nations, the Australian Institute of Criminology, as well as work conducted by Tsuya et al. (2000). Any gaps in the data were imputed using forecasting methods. As is common within GPI studies (see Lawn and Clarke, 2008), the final estimation of the GPI was partially a result of data availability.

The basis of the South Korean GPI is private consumption expenditure. This is reasonable as people's basic needs include food, water, shelter and clothing. However, not all personal consumption items are included in the GPI, as much consumption is wasteful, conspicuous or 
non-welfare-enhancing. Therefore, certain items of private consumption expenditure are excluded from the GPI calculations, this includes, spending on tobacco because of its health risks, but also spending on health and education (private and public), costs of vehicle accidents and insurance services (private consumption), defence, environmental protection, and public order and security (public consumption) as all this is rehabilitative or defensive expenditure. Private consumption expenditure on durable items is also excluded. Within GDP, it is assumed that all the benefits of these purchases flow immediately and in total at the time of purchase. However, it is more likely that the benefits (or services) of these consumer durables continue over a period of time (and well outside the time limits of a normal GDP reporting period of a single year).

To overcome this, expenditure on consumer durables is excluded from the GPI calculated but services from accrued consumer durables (normally accumulated expenditure on consumer durables for the last ten years) are added back in. An index assessing changes in income distribution is then applied to this adjusted personal consumption figure. The next two adjustments explicitly acknowledge that well-being can be enhanced beyond simple increases in personal consumption. Public infrastructure and non-paid household labour that enhance wellbeing are therefore added to the GPI. Unlike national accounts, explicit costs are associated with an expanding economy and subsequently subtracted from the GPI. Estimates of the costs of crime are made and removed as it is considered that an expanding economy can cause social pressures that exacerbate these social costs. It is assumed that less foreign debt enhances wellbeing, therefore changes in foreign debt are reflected as either additions or subtractions from the GPI. Environmental costs considered are limited to air pollution. The South Korean GPI is therefore a constructed index of these adjustments ${ }^{3}$.

\footnotetext{
${ }^{3}$ Given the extensive coverage of methodologies of GPI adjustments that have appeared over a period of time within Ecological Economics, and with the focus of this paper being less on the GPI itself and more on the drivers of
} 
Adjustments and the methodology undertaken in the South Korea GPI are listed in Table 2. The values of the GPI components are provided in Table A1 of the appendix.

\section{Insert Table 2}

\section{Determinants of GDP and theGPI Per Capita: Data and Methodology}

Data

After establishing the Korean GPI, the study now examines the determinants of GDP for South Korea then tests to see if the same variables which drive GDP also impact on the country's GPI. Annual data for the period 1970 to 2005 are employed. As this provides a relatively small number of data points, only a small number of explanatory variables are considered. The variables are selected based on theory and those found to be important in the literature review provided in Section 2. The variables considered are:

- Physical capital expenditure per capita;

- Export expenditure per capita;

- Research and development expenditure per capita;

- Inflation (percentage change in the consumer price index); and

- Human capital (defined as the number of South Koreans aged 15 years and over who had completed post-secondary education as a proportion of the population aged 15 years and over). ${ }^{4}$

GPI and GDP within South Korea, a fuller description of the methodologies associated with these adjustments are omitted but available from the authors on request.

${ }^{4}$ Other measures of human capital were considered, including the number of university students as a percentage of the population; the number of secondary school students; and the number of secondary students as a percentage of the population. These measures either had less available data than the chosen proxy, or did not give significantly different results. 
Per capita variables were used to adjust for the population increase of 25 per cent over the study period and all are measured in constant (2000) prices. Where the data were incomplete, values were imputed assuming a constant growth rate estimated from the data. Sources are given below in Table 3.

\section{Insert Table 3}

Table 4 presents summary statistics for each of the variables used in the model. Over the 36-year study period, the median GDP per capita was 6.3 million won $(\$ U S 5,544)$; however, by the end of the study period in 2005 , it had reached a value of 14.9 million won $(\$ U S 13,210)$. Over the same time period, the median GPI per capita exhibited a slightly lower result of 4.3 million won, but, like GDP per capita, reached its highest value at the end of the study period (10.7 million won), albeit approximately 4 million won lower than GDP per capita.

As with GDP per capita growth, exports per capita in South Korea have grown steadily over the study period, with a median value of 1.2 million won per year. Growth in research and development per capita has been relatively steady, with an annual median value of 100,000 won. Although physical capital per capita was growing at a relatively strong pace for the first 25 years of the study period, it experienced a large drop around the time of the Asian financial crisis, declining by almost 25 per cent from 1997 to 1998. It continued to grow after the Asian financial crisis, but at a slower pace than before.

Inflation in South Korea has been fairly volatile over the study period, particularly in the first decade. In 1980, South Korea's annual inflation rate was a staggering 28.7 per cent, triple its mean inflation rate of 8.7 per cent, thus requiring the use of constant prices in the analysis. 
The number of South Koreans who have completed tertiary education as a proportion of the population aged 15 years and over has been on a steady rise since the 1970s, apart from a dip at the end of the 1980s. As at 2005, 14 per cent of the South Korean labour force had completed tertiary education, compared with only 2.6 per cent of the labour force at the beginning of the study period in 1970 .

Only inflation and exports are found to be non-normal. In both cases, this is caused by positive skewness resulting from a large positive outlier. Stationarity is tested for each of the variables, using the Augmented Dickey-Fuller test. Inflation was the only variable that was stationary. The human capital variable exhibited a distinct structural break resulting from a change in government policy, which caused tertiary education enrolments in South Korea to soar by 2.5 times between 1980 to 1990 (Kim, 2002). To allow for this break, the Phillips-Perron test was applied, which found the series to be trend stationary. All remaining variables are integrated at order one.

\section{Insert Table 4}

\section{Insert Figure 1}

Figure 1 indicates that, over the 36-year study period from 1970 to 2005, the value of South Korea's GDP per capita has been consistently above its corresponding GPI per capita. From 1970 to 1973, South Korea's GDP per capita and GPI per capita were virtually the same, until the two values diverged in 1974 (this is a similar pattern to that experienced by neighbouring Thailand - see Clarke and Islam, 2004). This is a reflection of the trend of the weighted adjusted consumption expenditure, the decline of which can be attributed to a rise in the income distribution index during the same period. The 
increase in the distribution index is indicative of an expanding gap between the incomes of the wealthy and the poor, resulting in a dip in the GPI per capita.

In 1976, the GPI per capita increased until it reached a peak in 1979, and again in 1983. The peak in 1979 is the closest it would come to the level of GDP per capita within the study period since 1974. Again, a clear driver of the growth of GPI per capita in 1979 was the distribution index, which was only 89.9 during that year (the lowest level recorded during the entire period of interest). During the first half of the 1980s, although growth was sluggish for both GDP per capita and GPI per capita, growth in GPI per capita was still lower. This was consistent with the distribution index, which began to increase during this period, indicating a rise in income inequality.

From the mid-1980s till the Asian financial crisis in 1997-1998, the graph clearly displays an acceleration in both GDP per capita and GPI per capita, with both lines virtually parallel and a gap of approximately 2 million won (\$US2,000). This suggests that the drivers of GDP per capita during this period are also influencing the GPI per capita at the same rate. This is reflected in South Korea's GDP growth where, prior to 1998, the average rate was 7.8 per cent while the GPI growth rate was slightly lower at 7.5 per cent. According to the OECD (2003), South Korea's increase in the ratio of persons of working age (15 to 64 years of age) to the total population in the 1990 s was a key factor for the nation's rise in GDP per capita. During this time, most components of the GPI per capita also increased, namely weighted adjusted consumption expenditure, welfare capital and household labour. Combined with a decline in foreign debt, this led to rises in the GPI per capita. 
In 1997, both measures contract as a result of the Asian financial crisis, then rise again, with the GPI at a slower rate than GDP. After the Asian financial crisis, GDP and GPI growth rates started to diverge significantly, with GDP growth averaging 5.8 per cent and GPI growth only averaging 3.3 per cent. This could be due to a number of factors: a steady increase in income inequality, stagnation in welfare capital, and the massive foreign debt incurred as a result of the IMF bailout in 1998. GPI per capita growth appears to taper off towards the end of the study period, while GDP per capita is observed to be growing at a solid rate. The increasing divergence between the two measures reveals that, despite GDP per capita indicating an ongoing expansion in economic activity, South Korea's citizens are not as well off as this might suggest if taking into consideration social and environmental factors. Therefore, GDP may well overstate the nation's true level of well-being.

\section{Methodology}

To investigate determinants of South Korea's growth and genuine progress, a model is estimated that incorporates all variables considered to be drivers of GDP per capita as discussed above. The variables have all been made stationary. Inflation needs no adjustment, but human capital is de-trended and all the remaining variables are differenced once. The model is specified as:

$$
\Delta y_{t}=\beta_{o}+\Delta \beta_{1} X_{t}+\Delta \beta_{2} R D_{t}+\Delta \beta_{3} K_{t}+D E T R E N D \beta_{4} H C_{t}+\beta_{5} I N F_{t}+\varepsilon_{t}
$$

\section{Where:}

$\Delta y_{t}=$ Change in value of South Korea's GDP per capita at time $t$ or change in value of South Korea's GPI per capita at time $t$, as applicable ;

$\Delta X_{t}=$ Change in value of South Korea's exports per capita at time $t$, 
$\Delta R D_{t}=$ Change in value of South Korea's research and development per capita at time $t$, $\Delta K_{t}=$ Change in value of South Korea's investment in physical capita at time $t$,

DETRENDHC $_{t}=$ Number of South Koreans who have completed post-secondary education as a percentage of the population aged 15 years and over after detrending, at time $t$, and

$I N F_{t}=$ South Korea's annual inflation rate at time $t$.

To check the model specification, a second model incorporates an inflation squared variable to test for a non-linear impact and as there was a noticeable drop in GDP in 1998 due to the Asian financial crisis, a dummy variable was included in a third model to account for this effect. These models omit the human capital variable as it was found to be insignificant.

Cointegration is tested for using the Johansen test, with both the Trace and Maximum Eigenvalue forms of the test considered. An error correction form of the final model is then estimated. In the first stage, the long-run or equilibrium equation is estimated using only the levels of the difference stationary variables as shown in equation (2).

$$
y_{t}=\alpha_{o}+\alpha_{1} X_{t}+\alpha_{2} R D_{t}+\alpha_{3} K_{t}+u_{t}
$$

The lagged residuals from this equation (ECV), which measure how far $y_{t}$ was from its long-run value in the previous period, are then used as an explanatory variable in an equation based on (1) to measure the return to equilibrium as shown in equation (3) below.

$$
\Delta y_{t}=\beta_{o}+\Delta \beta_{1} X_{t}+\Delta \beta_{2} R D_{t}+\Delta \beta_{3} K_{t}+\beta_{5} I N F_{t}-\lambda E C V_{t-1}+\varepsilon_{t}
$$

\section{Results and discussion}




\section{GDP per capita model}

This section provides the results from the estimation of the empirical models. Table 5 presents results using GDP per capita as the dependent variable. The t-statistics are adjusted for heteroskedasticity and correlation using the Newey-West adjustment.

The coefficients in the base model all have the expected sign, but the coefficient on the human capital variable is not significant at conventional levels of significance, so is omitted from remaining models. Neither the inclusion of the non-linear inflation term or the 1998 dummy variable significantly improve the model. The final specification includes exports, R\&D, physical capital and inflation (with inflation having the expected negative association with GDP per capita and all other variables a positive association). The coefficient on exports is only significant at the 10 per cent level, but other coefficients are significant at the 5 per cent level.

\section{Insert Table 5}

The variables in the final model were then tested for cointegration using the Johansen test. The p-values of the two unrestricted cointegration rank tests were 0.0006 and 0.0031 for the Trace and Maximum Eigenvalue tests, respectively. Therefore, the null hypothesis of no cointegrating relationship was rejected against the alternative hypothesis of at least one cointegrating relationship using a level of significance equal to 5 per cent. When the error correction model was fitted, the coefficient of the error correction term was estimated to be -0.0058 , with a $\mathrm{p}$-value of 0.9507 . As this coefficient was insignificant and showed an excessively slow return to equilibrium (over 100 years), the model was not considered appropriate. 


\section{GPI per capita model}

Table 6 presents the results of the four GPI models using the same methodology as the GDP per capita models. Similar to the GDP per capita results, there is no significant impact from the 1998 dummy variable.

Although the model including the quadratic inflation terms appears to be superior based on the statistical measures, the response function is not reasonable. It shows GPI increasing with inflation, peaking at a level of 13.7 per cent; inflation does not have a negative impact until it exceeds 27.5 per cent. Therefore, this model was rejected.

For comparison, the same final model was fitted as for GDP per capita. This proved to have superior performance to all but the rejected quadratic inflation model based on the consistent model selection criteria of Schwartz and Hannan-Quinn. This model shows that only physical capital has a statistically significant impact on GPI. The coefficients on the inflation and $\mathrm{R} \& \mathrm{D}$ variables have the expected signs but are not significant. 


\section{Insert Table 6}

The variables from this final model were tested for cointegration, again using the Johansen test. Similarly to the GDP per capita case, the null hypothesis of no cointegrating relationship was rejected but not the null hypothesis of at most one cointegrating relationship using a level of significance of 5 per cent.

Table 7 presents the results of the GPI error correction model. Consistent with the GDP per capita long-run error correction model, physical capital per capita is again found to be statistically significant at the 1 per cent level, indicating a strong long term relationship with GPI per capita growth. Although exports and research per capita exhibit positive coefficients, they are not statistically significant.

\section{Insert Table 7}

When the short-run equation of the error correction model is estimated, the coefficient of the error correction variable had the correct coefficient sign, and was found to be statistically significant at the 5 per cent level, showing a rapid return to the long-run relationship. Despite positive coefficients for the exports and R\&D variables, these were not found to be statistically significant, unlike physical capital. The error correction model indicates that there is a stable long-run relationship between physical capital and the GPI per capita, but none of the other variables commonly found to impact GDP per capita affect the GPI per capita. 
These results indicate that while physical capital, research and development, exports, and inflation are all important in determining South Korea's GDP per capita, only physical capital is found to have a significant positive effect on genuine progress once social and environmental aspects of economic growth are considered. The drivers of GDP per capita clearly differ vis-à-vis the GPI per capita.

\section{Conclusion}

The 2008 global financial crisis served as a timely reminder of the risk associated with the relentless pursuit of material growth. Utilising indicators that provide a more holistic evaluation of a nation's progress broadens understandings of how actions within an economy influence its other parts. This paper calculated a GPI for South Korea and analysis was conducted to determine if the drivers of economic growth in South Korea are the same ones that drive growth in the GPI. While the GPI and GDP did track in tandem for the first 15 years of the study period, an increasing divergence occurred following the 1997 Asian Financial Crisis. The increasing divergence between the two measures reveal that South Korea's citizens are not as well off as GDP per capita suggests once social and environmental aspects of economic growth are considered. GDP may therefore overstate a nation's true progress.

To explore the difference between GDP and GPI per capita further, several empirical models developed by the study were estimated. The results of the study find that the variables that drive growth in GDP per capita in South Korea are different to those that drive growth in GPI per capita. While physical capital, research and development, exports, and inflation are all important in determining South Korea's GDP per capita, once social and environmental aspects of economic growth are taken into account, only 
physical capital is found to have a significant positive effect on genuine progress. Public policy that preferences physical capital over other drivers will therefore have greater impact on enhancing genuine progress.

The difference in the drivers of GDP per capita and GPI per capita suggests that policy makers should not rely solely on GDP per capita as an indication of the well-being of a nation. Before making decisions, policy makers should seek additional social and environmental data that will provide a more comprehensive perspective of a nation's status. There is value, therefore, in considering the drivers of genuine progress in other countries (including developed countries) to determine if these elements are largely standard across economies or differ on a country-to-country basis. Over time, as this practice becomes more common and measures such as the GPI are utilised, the use of genuine progress indicators will become more mainstream and be adopted more willingly. To facilitate this it would be valuable to greater consistency of datasets for the construction of GPIs between countries. This consistency would also allow provide greater opportunities to consider policy implications across countries and regions. 


\section{References}

Abramovitz, M. (1961), 'The Welfare Interpretation of Secular Trends in National Income and Product' in M. Abramovitz et al. (eds) The Allocation of Economic Resources, Stanford University Press, Stanford.

Barro, R.J. and Lee, J.W. (2000), 'International Data on Educational Attainment: Updates and Implications', Appendix Table A2, Harvard University, February.

Cheong, K.S. (2001), 'Economic Crisis and Income Inequality in Korea', Asian Economic Journal, vol. 15, no. 1, pp. 39-60.

Chul-Kyoo, K. (2004), 'Impact of Korea's Economic Development on Social Conditions', Korea Focus, vol. 12, no. 3, pp. 114-131.

Chun, B.C. (2003), 'Effects of Financial Liberalization on Consumption in Korea', The Bank of Korea Economic Papers, vol. 6, no. 1, pp. 24-41.

Clarke, M. and Islam, S. (2004), Economic Growth and Social Welfare: Operationalising Normative Social Choice Theory, (published in Contribution to Economic Analysis series, Vol. 262) North Holland, Amsterdam.

Commission on Growth and Development (2009). The Growth Report: Strategies For Sustained Growth And Inclusive Development, World Bank, Washington.

Daly, H. and Cobb J. (1990), For the Common Good, Beacon Press, Boston.

Davis, J.C. and Gonzalez, J.G. (2003), 'Scholarly Journal Articles about the Asian Tiger Economies: Authors, Journals and Research Fields, 1986-2001', Asian-Pacific Economic Literature, vol 17, no. 2, pp. 51-61.

Diefenbacher. H. (1994), 'The Index of Sustainable Economic Welfare' in J. Cobb and C. Cobb (eds), The Green National Product, University Press of America, Lanham.

Dietz, S. and Neumayer, E. (2006) 'Some constructive criticisms of the index of sustainable economic welfare', in P. Lawn, (ed.) Sustainable development indicators in ecological economics. Edward Elgar, Cheltenham, UK,

G20 (2010), G20 Seoul Summit 2010, Seoul Development Consensus for Shared Growth, Annex,

<http://www.g20.org/Documents2010/11/seoulsummit_annexes.pdf> [accessed September 15 ${ }^{\text {th }}$ 2011]

Guardian (2009) Sarkozy attacks focus on economic growth, $<$ http://www.guardian.co.uk/business/2009/sep/14/sarkozy-attacks-gdpfocus

$>$ [accessed September $15^{\text {th }} 2011$ ]

Hamilton, C. (1998), 'Measuring Changes in Economic Welfare' in R. Eckersley (ed.), Measuring Progress, CSIRO Publishing, Melbourne.

Harvie, C. and Lee, H. (2003), Korea's Economic Miracle: Fading or Reviving?, Palgrave MacMillan, New York.

Harvie, C. and Pahlavani, M. (2007), 'Sources of Economic Growth in South Korea: An Application of the ARDL Analysis in the Presence of Structural Breaks - 19802005', The Journal of the Korean Economy, vol. 8, no. 2, pp. 205-35.

IMF (2007), International Monetary Fund International Financial Statistics Online, viewed 7 August 2007, <http://www.imfstatistics.org/imf/logon.aspx>.

Jackson, T. and Marks, N. (1994), Measuring Sustainable Economic Welfare, Stockholm Environment Institute in cooperation with The New Economics Foundation, Stockholm.

Joo, H. (2003), 'Crime and Crime Control', Social Indicators Research, vol. 62, no. 1, pp. 239-63.

Kang, J.M. (2006), 'An Estimation of Growth Model for South Korea Using Human Capital', Journal of Asian Economics, vol. 17, no. 5, pp. 852-66. 
Kim, G. (2002), 'Education Policies and Reform in South Korea' (chapter 3), in 'Secondary Education in Africa: Strategies for Renewal', vol. 1, Departmental working paper, World Bank

KOSIS (2010), Statistical Database, viewed 5 July 2010, $<$ http://www.kosis.kr/eng/database/database_001000.jsp?listid $=$ B\&subtitle=Po pulation, Household. $>$

Kuznets, S. (1941) National Income and It's Composition: 1919-1938, National Bureau of Economic Research, New York.

Kwack, S.Y. and Lee, Y.S (2006), 'Analyzing Korea's growth experience: The application of R\&D and human capital based growth models with demography', Journal of Asian Economics, vol. 17, pp. 818-31.

Kwon, O.Y. (2005), 'A Cultural Analysis of South Korea's Economic Prospects', Global Economic Review, vol. 34, no. 2, pp. 213-31.Lawn, P. (2003), 'A theoretical foundation to support the Index of Sustainable Economic Welfare (ISEW), Genuine Progress Indicator (GPI), and other related measures', Ecological Economics, 44, pp. 105-118.

Lawn, P. and Clarke, M. (2006), Measuring Genuine Progress: An Application of The Genuine Progress Indicator, Nova Science, New York.

Lawn, P. and Clarke, M. (2008), Sustainable Welfare in the Asia-Pacific: Studies Using the Genuine Progress Indicator, Edward Elgar, London.

Lawn, P. and Sanders, R. (1999), 'Has Australia Surpassed its Optimal Macroeconomic Scale? Finding Out with the Aid of "Benefit" and "Cost" Accounts and a Sustainable Net Benefit Index', Ecological Economics, Vol. 28, pp. 213-299.

Lee, M., Liu, B. and Wang, P. (1994), 'Education, Human Capital Enhancement and Economic Development: Comparison Between Korea and Taiwan', Economics of Education Review, vol. 13, no. 4, pp. 275-288.

Mayhew, P. (2003), 'Counting the Costs of Crime in Australia', Australian Institute of Criminology, no. 247, April.

Neumayer, E. (1999), 'The ISEW - Not an Index of Sustainable Economic Welfare', Social Indicators Research, Vol. 40, pp. 77-101.

Nordhaus, W. and Tobin, J. (1973), 'Is Growth Obsolete?,' in M. Moss (ed.) The Measurement of Economic and Social Planning, Economic Growth, National Bureau of Economic Research, New York.

OECD (2003), The Sources of Economic Growth in OECD Countries, France.

OECD (2008a), Distribution of Gross Earnings of Full-Time Employees, viewed 2 February 2008, <http://stats.oecd.org/wbos/default.aspx?DatasetCode=MW_CURP.>

OECD (2008b), Stat Extracts, viewed 1 August 2008, <http://www.oecd.org/document/63/0,3343,en_2825_495670_38939455_1_1_ 1_1,00.html.>

Park C., and Shin, D.C. (2005), 'Perception of Life Quality Among the Korean Mass Public: Unravelling their Dynamics and Standards', Social Indicators Research, vol. 70, no. 1, pp. 257-286.

Piazolo, M. (1995), 'Determinants of South Korean Economic Growth 1955-1990', International Economic Journal, vol. 9, no. 4, pp. 109-133.

Republic of Korea Ministry of Environment (2006), Green Korea, South Korea.

Rosenberg, D., and Oegema, T. (1995), A Pilot Index of Sustainable Economic Welfare for the Netherlands, 1952 to 1992, Institute for Environment and Systems Analysis, Amsterdam.

Sametz, A. (1968), 'Production of Goods and Services: The Measurements of Economic Growth' in E. Sheldon and W. Moore (eds), Indicators of Social Change, Russell Sage Foundation, New York. 
Sengupta, J.K. and Espana, J.R. (1994), 'Exports and Economic Growth in Asian NICs: An Econometric Analysis for Korea', Applied Economics, vol. 26, pp. 41-51.

South Korean Ministry of Education, Science \& Technology (2008), Total R\&D Expenditure, viewed 18 October 2011, < http://english.mest.go.kr/web/1751/site/contents/en/en 0240.jsp>

Stockhammer, L., Hochrieter, F., Obermayer, B. and Steiner, K. (1997), 'The Index of Sustainable Economic Welfare. The Results of the Austrian (revised) ISEW Calculations 1955-1992', Ecological Economics, Vol. 21, pp. 19-34.

Tsuya, N.O., Bumpass, L.L., Choe, M.K. (2000), 'Gender, Employment, and Housework in Japan, South Korea, and the United States', Review of Population and Social Policy, vol. 9, pp. 195-220.

United Nations Office on Drugs and Crime (2010), Data and Analysis, viewed 7 July 2010, $<$ http://www.unodc.org/unodc/en/data-andanalysis/index.html?ref $=$ menuside. $>$

World Bank (2008), Data: Republic of Korea, viewed 25 November 2008, $<$ http://data.worldbank.org/country/korea-republic.>

Yang, O.K. (2003), 'Family Structure and Relations', Social Indicators Research, vol. 62, no. 1, pp. 121-148.

Yuhn, K. and Kwon, J.K. (2000), 'Economic Growth and Productivity: A Case Study of South Korea', Applied Economics, vol. 32, pp. 13-23.

\section{Appendix}

Table A1: GPI component values for South Korea

\begin{tabular}{|c|c|c|c|c|c|c|c|c|}
\hline Year & $\begin{array}{c}\text { Adj. Cons. } \\
\text { (weighted) } \\
\text { (billion } \\
\text { won) }\end{array}$ & $\begin{array}{l}\text { Welf Cap } \\
\text { (billion } \\
\text { won) }\end{array}$ & $\begin{array}{l}\text { Household } \\
\text { Labour } \\
\text { (billion } \\
\text { won) }\end{array}$ & $\begin{array}{c}\text { Foreign } \\
\text { Debt } \\
\text { (billion } \\
\text { won) }\end{array}$ & $\begin{array}{l}\text { Crime } \\
\text { (billion } \\
\text { won) }\end{array}$ & $\begin{array}{c}\text { Air } \\
\text { Pollution } \\
\text { (billion } \\
\text { won) }\end{array}$ & $\begin{array}{c}\text { GPI } \\
\text { (billion } \\
\text { won) }\end{array}$ & $\begin{array}{c}\text { GPI per } \\
\text { capita } \\
\text { (million } \\
\text { won) }\end{array}$ \\
\hline & + & + & + & - & - & - & & \\
\hline 1970 & 61431.033 & 50.683 & 6590.738 & 18.212 & 0.079 & 0.001 & 68054.163 & 2.132 \\
\hline 1971 & 64334.861 & 60.625 & 6984.684 & 51.854 & 0.060 & 0.001 & 71328.256 & 2.188 \\
\hline 1972 & 68588.320 & 72.518 & 7519.655 & -84.619 & 0.050 & 0.002 & 76265.060 & 2.293 \\
\hline 1973 & 74948.115 & 86.745 & 8758.700 & -61.183 & 0.038 & 0.002 & 83854.703 & 2.471 \\
\hline 1974 & 71160.896 & 103.761 & 8471.461 & 81.348 & 0.038 & 0.003 & 79654.729 & 2.302 \\
\hline 1975 & 67056.507 & 124.117 & 8127.321 & -0.760 & 0.050 & 0.004 & 75308.651 & 2.135 \\
\hline 1976 & 78719.822 & 155.698 & 10017.650 & 40.830 & 0.056 & 0.005 & 88852.279 & 2.479 \\
\hline 1977 & 83669.395 & 207.339 & 11279.743 & -277.630 & 0.119 & 0.007 & 95433.981 & 2.621 \\
\hline 1978 & 97661.048 & 256.886 & 13674.166 & 331.560 & 0.083 & 0.009 & 111260.448 & 3.010 \\
\hline 1979 & 117988.579 & 349.623 & 16764.800 & 684.300 & 0.182 & 0.011 & 134418.509 & 3.581 \\
\hline 1980 & 114123.817 & 449.600 & 15879.904 & 827.610 & 0.100 & 0.014 & 129625.597 & 3.400 \\
\hline 1981 & 114303.059 & 630.541 & 16318.900 & 1264.400 & 0.115 & 0.017 & 129987.968 & 3.357 \\
\hline 1982 & 124413.431 & 840.561 & 18283.254 & 2401.930 & 0.125 & 0.019 & 141135.171 & 3.589 \\
\hline 1983 & 131335.917 & 952.065 & 20109.463 & 311.470 & 0.157 & 0.022 & 152085.796 & 3.811 \\
\hline 1984 & 124556.054 & 1149.273 & 19657.745 & 1258.370 & 0.142 & 0.025 & 144104.534 & 3.566 \\
\hline 1985 & 129660.869 & 1391.304 & 20857.621 & 2107.200 & 0.200 & 0.028 & 149802.365 & 3.671 \\
\hline 1986 & 136825.321 & 1389.112 & 23072.096 & -1392.490 & 0.190 & 0.032 & 162678.796 & 3.950 \\
\hline 1987 & 141358.191 & 1507.752 & 25030.732 & -3615.550 & 0.175 & 0.038 & 171512.013 & 4.125 \\
\hline 1988 & 156771.898 & 1755.916 & 28715.320 & -2791.740 & 0.182 & 0.044 & 190034.649 & 4.527 \\
\hline 1989 & 184225.460 & 1841.076 & 33401.664 & 62.370 & 0.240 & 0.049 & 219405.541 & 5.177 \\
\hline 1990 & 203890.938 & 2054.302 & 37213.533 & -782.890 & 0.242 & 0.059 & 243941.361 & 5.690 \\
\hline
\end{tabular}




\begin{tabular}{|c|c|c|c|c|c|c|c|c|}
\hline Year & $\begin{array}{c}\text { Adj. Cons. } \\
\text { (weighted) } \\
\text { (billion } \\
\text { won) }\end{array}$ & $\begin{array}{c}\text { Welf Cap } \\
\text { (billion } \\
\text { won) }\end{array}$ & $\begin{array}{c}\text { Household } \\
\text { Labour } \\
\text { (billion } \\
\text { won) }\end{array}$ & $\begin{array}{c}\text { Foreign } \\
\text { Debt } \\
\text { (billion } \\
\text { won) }\end{array}$ & $\begin{array}{c}\text { Crime } \\
\text { (billion } \\
\text { won) }\end{array}$ & $\begin{array}{c}\text { Air } \\
\text { Pollution } \\
\text { (billion } \\
\text { won) }\end{array}$ & $\begin{array}{c}\text { GPI } \\
\text { (billion } \\
\text { won) }\end{array}$ & $\begin{array}{c}\text { GPI per } \\
\text { capita } \\
\text { (million } \\
\text { won) }\end{array}$ \\
\hline 1991 & $\mathbf{+}$ & + & + & - & - & - & & \\
\hline 1992 & 263487.646 & 2514.310 & 41638.628 & 1885.300 & 0.326 & 0.071 & 265754.887 & 6.142 \\
\hline 1993 & 278736.679 & 3926.203 & 52488.833 & -2521.500 & 0.785 & 0.089 & 337672.341 & 7.665 \\
\hline 1994 & 291937.098 & 4277.052 & 55939.735 & 1326.900 & 0.864 & 0.103 & 350826.017 & 7.892 \\
\hline 1995 & 318750.930 & 5077.237 & 61449.342 & 2636.200 & 1.110 & 0.120 & 382640.079 & 8.486 \\
\hline 1996 & 342708.586 & 6607.411 & 65847.018 & 5007.800 & 1.091 & 0.134 & 410153.990 & 9.009 \\
\hline 1997 & 361762.191 & 8726.757 & 70194.751 & -15918.200 & 0.971 & 0.145 & 456600.784 & 9.936 \\
\hline 1998 & 340234.865 & 13196.182 & 66534.814 & 2246.400 & 0.711 & 0.141 & 417718.609 & 9.025 \\
\hline 1999 & 332510.795 & 13272.917 & 66194.096 & -2351.000 & 0.821 & 0.153 & 414327.834 & 8.888 \\
\hline 2000 & 362270.990 & 13382.980 & 73801.640 & -4142.800 & 0.873 & 0.166 & 453597.372 & 9.649 \\
\hline 2001 & 374665.223 & 15347.379 & 75699.217 & 3410.800 & 1.063 & 0.176 & 462299.780 & 9.762 \\
\hline 2002 & 394885.083 & 14432.913 & 79895.300 & 21773.400 & 0.942 & 0.192 & 467438.762 & 9.816 \\
\hline 2003 & 400792.188 & 16828.600 & 83047.292 & 2378.500 & 0.746 & 0.201 & 498288.633 & 10.412 \\
\hline 2004 & 397863.475 & 17854.385 & 86037.491 & -3610.000 & 0.746 & 0.214 & 505364.391 & 10.520 \\
\hline 2005 & 413797.894 & 19391.288 & 90635.845 & 5911.900 & 0.795 & 0.219 & 517912.113 & 10.759 \\
\hline
\end{tabular}


Table 1: Standard GPI Adjustments

\begin{tabular}{lc}
\hline \multicolumn{1}{c}{ Item } & $\begin{array}{c}\text { Welfare } \\
\text { contribution }\end{array}$ \\
\hline Consumption (private and public) expenditure & + \\
Defensive and rehabilitative expenditures & - \\
Expenditure on consumer durables & - \\
Service from consumer durables & + \\
Distribution Index & $+/-$ \\
Welfare generated by publicly-provided infrastructure & + \\
Value of non-paid household labour & + \\
Value of volunteer labour & + \\
Cost of unemployment and underemployment & - \\
Cost of crime & - \\
Cost of family breakdown & - \\
Change in foreign debt position & $+/-$ \\
Cost of non-renewable resource depletion & - \\
Cost of lost agricultural land & - \\
Cost of timber depletion & - \\
Cost of air pollution & - \\
Cost of waste-water pollution & - \\
Cost of long-term environmental damage & - \\
\hline
\end{tabular}


Table 2: GPI data sources

\begin{tabular}{|c|c|c|c|c|}
\hline Variable & Source & Details & Frequency & Time period available \\
\hline $\begin{array}{l}\text { Private } \\
\text { consumption } \\
\text { expenditure }\end{array}$ & $\begin{array}{l}\text { World Bank } \\
\text { (2008) }\end{array}$ & $\begin{array}{l}\text { 'Household final consumption } \\
\text { expenditure (constant billion won)' }\end{array}$ & Annual & $1970-2005$ \\
\hline $\begin{array}{l}\text { Public } \\
\text { consumption } \\
\text { expenditure } \\
\end{array}$ & $\begin{array}{l}\text { World Bank } \\
\text { (2008) }\end{array}$ & $\begin{array}{l}\text { 'General government final } \\
\text { consumption expenditure (constant } \\
\text { billion won)' }\end{array}$ & Annual & $1970-2005$ \\
\hline $\begin{array}{l}\text { Expenditure } \\
\text { on consumer } \\
\text { durables } \\
(\text { ECD) }\end{array}$ & $\begin{array}{l}\text { KOSIS } \\
(2010)\end{array}$ & $\begin{array}{l}\text { 'Expenditure of consumer durables } \\
\text { (constant billion won)' }\end{array}$ & Annual & $1970-2005$ \\
\hline $\begin{array}{l}\text { Service from } \\
\text { consumer } \\
\text { durables } \\
\text { (SCD) }\end{array}$ & Derived & $\begin{array}{l}\text { Derived from adding previous ten } \\
\text { years of expenditure on consumer } \\
\text { durables to arrive at stock of } \\
\text { consumer durables, and then } \\
\text { multiplying by } 0.1(10 \%)\end{array}$ & Annual & $\begin{array}{l}1970-2005 \\
\text { Values for 1970-1979 were } \\
\text { calculated using backcasting } \\
\text { of average growth rates }\end{array}$ \\
\hline $\begin{array}{l}\text { Distribution } \\
\text { index (DI) }\end{array}$ & $\begin{array}{l}\text { OECD } \\
(2008 \mathrm{a})\end{array}$ & $\begin{array}{l}\text { Data comprised of two types: } \\
\text { - GMF1 (both sexes): gross } \\
\text { monthly earnings (including } \\
\text { overtime and one twelfth of annual } \\
\text { bonuses) of full-time South Korean } \\
\text { workers. } \\
\text { GMF1 data was available from } 1975 \\
\text { to } 2000 \text { (mean values from } 1975 \text { to } \\
2000, \text { median values from } 1984 \text { to } \\
\text { 2000). } \\
\text { - GMF0 (both sexes): gross } \\
\text { monthly earnings (excluding } \\
\text { overtime and one twelfth of annual } \\
\text { bonuses) of full-time South Korean } \\
\text { workers. } \\
\text { GMF0 data was available from } 2000 \\
\text { to } 2005 \text { (median values). }\end{array}$ & Annual & $\begin{array}{l}1970-2005 \\
\text { A number of steps were } \\
\text { involved in calculating a time } \\
\text { series of real gross annual } \\
\text { income and therefore the } \\
\text { distribution index (refer to } \\
\text { Section } 5.1 \text { for further detail). }\end{array}$ \\
\hline $\begin{array}{l}\text { Welfare from } \\
\text { publicly- } \\
\text { provided } \\
\text { service } \\
\text { capital } \\
\text { (WPPSC) }\end{array}$ & Derived & $\begin{array}{l}\text { Assumed to be equal to } 75 \text { per cent } \\
\text { of the public sector consumption of } \\
\text { fixed capital. }\end{array}$ & Annual & $1970-2005$ \\
\hline $\begin{array}{l}\text { Value of } \\
\text { non-paid } \\
\text { household } \\
\text { labour }(\mathrm{HL})\end{array}$ & $\begin{array}{l}\text { Tsuya et al. } \\
\text { (2000); } \\
\text { OECD } \\
\text { (2008b). }\end{array}$ & $\begin{array}{l}\text { Hours of household labour based } \\
\text { on study by Tsuya et al. (2000); } \\
\text { minimum wage rate obtained from } \\
\text { OECD (2008). } \\
\text { The annual value of household } \\
\text { labour per household multiplied by } \\
\text { number of households. }\end{array}$ & Annual & $\begin{array}{l}1970-2005 \\
\text { Data for number of } \\
\text { household labour hours } \\
\text { available for } 1994 \text {. The } \\
\text { number of hours for other } \\
\text { years is reduced by } 1 \text { per cent } \\
\text { each year due to labour- } \\
\text { reducing technologies based } \\
\text { on assumption by Lawn and } \\
\text { Clarke (2006). }\end{array}$ \\
\hline $\begin{array}{l}\text { Change in } \\
\text { foreign debt } \\
\text { position } \\
\text { (FORDEBT) }\end{array}$ & IMF (2007) & $\begin{array}{l}\text { To calculate South Korea's net } \\
\text { foreign debt, the nation's foreign } \\
\text { assets were deducted from its } \\
\text { foreign liabilities. }\end{array}$ & Annual & $1970-2005$ \\
\hline $\begin{array}{l}\text { Cost of } \\
\text { crime }(\mathrm{CR})\end{array}$ & $\begin{array}{l}\text { United } \\
\text { Nations } \\
\text { Crime } \\
\text { Surveys } \\
\text { (2010); } \\
\text { Australian }\end{array}$ & $\begin{array}{l}\text { The number of different categories } \\
\text { of crime obtained from United } \\
\text { Nations Crime Surveys and then } \\
\text { multiplied by crime costs as } \\
\text { calculated by the Australian } \\
\text { Institute of Criminology }\end{array}$ & Annual & $\begin{array}{l}1970-2005 \\
\text { There were missing data for } \\
\text { all categories of crime, so } \\
\text { these values were interpolated. }\end{array}$ \\
\hline
\end{tabular}




\begin{tabular}{|c|c|c|c|c|}
\hline Variable & Source & Details & Frequency & Time period available \\
\hline & $\begin{array}{l}\text { Institute of } \\
\text { Criminology } \\
\text { (Mayhew } \\
\text { 2003) }\end{array}$ & & & \\
\hline $\begin{array}{l}\text { Cost of air } \\
\text { pollution } \\
\text { (AIR) }\end{array}$ & $\begin{array}{l}\text { Republic of } \\
\text { Korea } \\
\text { Ministry of } \\
\text { Environment } \\
(2006)\end{array}$ & $\begin{array}{l}\text { To calculate the cost of air } \\
\text { pollution, three assumptions are } \\
\text { made (following Lawn and Clarke } \\
\text { 2006): } \\
\text { 1. air pollution is closely related to } \\
\text { the level of production within an } \\
\text { economy, and therefore is positively } \\
\text { correlated with the nation's GDP; } \\
2 . \text { air pollution abatement } \\
\text { technology improves at the rate of } \\
1 \% \text { per annum, constantly reducing } \\
\text { the impact of a per unit of } \\
\text { production on air quality; and } \\
3 \text {. air pollution damage cost is } \\
\text { assumed to be ten times control } \\
\text { cost. }\end{array}$ & Annual & $\begin{array}{l}\text { 1970-2005 } \\
\text { The cost of controlling air } \\
\text { pollution was available for } \\
\text { 2003. Values for other years } \\
\text { were based on the assumption } \\
\text { that air pollution is closely } \\
\text { related to the level of } \\
\text { economic growth. }\end{array}$ \\
\hline
\end{tabular}


Table 3: Determinants of GDP: variables and sources

\begin{tabular}{|c|c|c|c|c|}
\hline Variable & Source & Details & Frequency & $\begin{array}{l}\text { Time period } \\
\text { available }\end{array}$ \\
\hline $\begin{array}{l}\text { Real GDP } \\
\text { per capita } \\
\text { (value level) }\end{array}$ & $\begin{array}{l}\text { World Bank } \\
(2008)\end{array}$ & 'GDP per capita (constant billion Won)' & Annual & $1970-2005$ \\
\hline $\begin{array}{l}\text { Physical } \\
\text { capital } \\
\text { expenditure } \\
\text { per capita } \\
\text { (value level) }\end{array}$ & $\begin{array}{l}\text { World Bank } \\
(2008)\end{array}$ & $\begin{array}{l}\text { 'Gross fixed capital formation (constant } \\
\text { billion Won)' divided by 'Population, } \\
\text { total'. }\end{array}$ & Annual & $1970-2005$ \\
\hline $\begin{array}{l}\text { Export } \\
\text { expenditure } \\
\text { per capita } \\
\text { (value level) }\end{array}$ & $\begin{array}{l}\text { World Bank } \\
(2008)\end{array}$ & $\begin{array}{l}\text { 'Exports of goods and services } \\
\text { (constant billion Won)' divided by } \\
\text { 'Population, total'. }\end{array}$ & Annual & $1970-2005$ \\
\hline $\begin{array}{l}\text { Inflation } \\
\text { (growth rate) }\end{array}$ & $\begin{array}{l}\text { World Bank } \\
(2008)\end{array}$ & 'Inflation, consumer prices (annual \%)'. & Annual & $1970-2005$ \\
\hline $\begin{array}{l}\text { Research and } \\
\text { development } \\
\text { expenditure } \\
\text { per capita } \\
\text { (value level) }\end{array}$ & $\begin{array}{l}\text { South } \\
\text { Korean } \\
\text { Ministry of } \\
\text { Education, } \\
\text { Science \& } \\
\text { Technology } \\
(2008)\end{array}$ & $\begin{array}{l}\text { 'Total R\&D expenditure (constant } \\
\text { billion Won' divided by World Bank, } \\
\text { 'Population, total'. }\end{array}$ & $\begin{array}{l}\text { Every } 5 \text { years } \\
\text { between } 1970 \text { and } \\
1995 \text { and then } \\
\text { every year from } \\
1996 \text { to } 2005 \text {. }\end{array}$ & $1970-2005$ \\
\hline $\begin{array}{l}\text { Human } \\
\text { capital (\%) }\end{array}$ & $\begin{array}{l}\text { Barro and } \\
\text { Lee (2001) }\end{array}$ & $\begin{array}{l}\text { Number of South Koreans who have } \\
\text { completed post-secondary education as } \\
\text { a proportion of the population aged } 15 \\
\text { and over. }\end{array}$ & $\begin{array}{l}\text { Every } 5 \text { years } \\
\text { between } 1970 \text { and } \\
2000 .\end{array}$ & 1970-2005 \\
\hline Population & $\begin{array}{l}\text { World Bank } \\
\text { (2008) }\end{array}$ & Used in calculation of other variables & Annual & $1970-2005$ \\
\hline
\end{tabular}


Table 4: Summary statistics: GDP and GPI variables

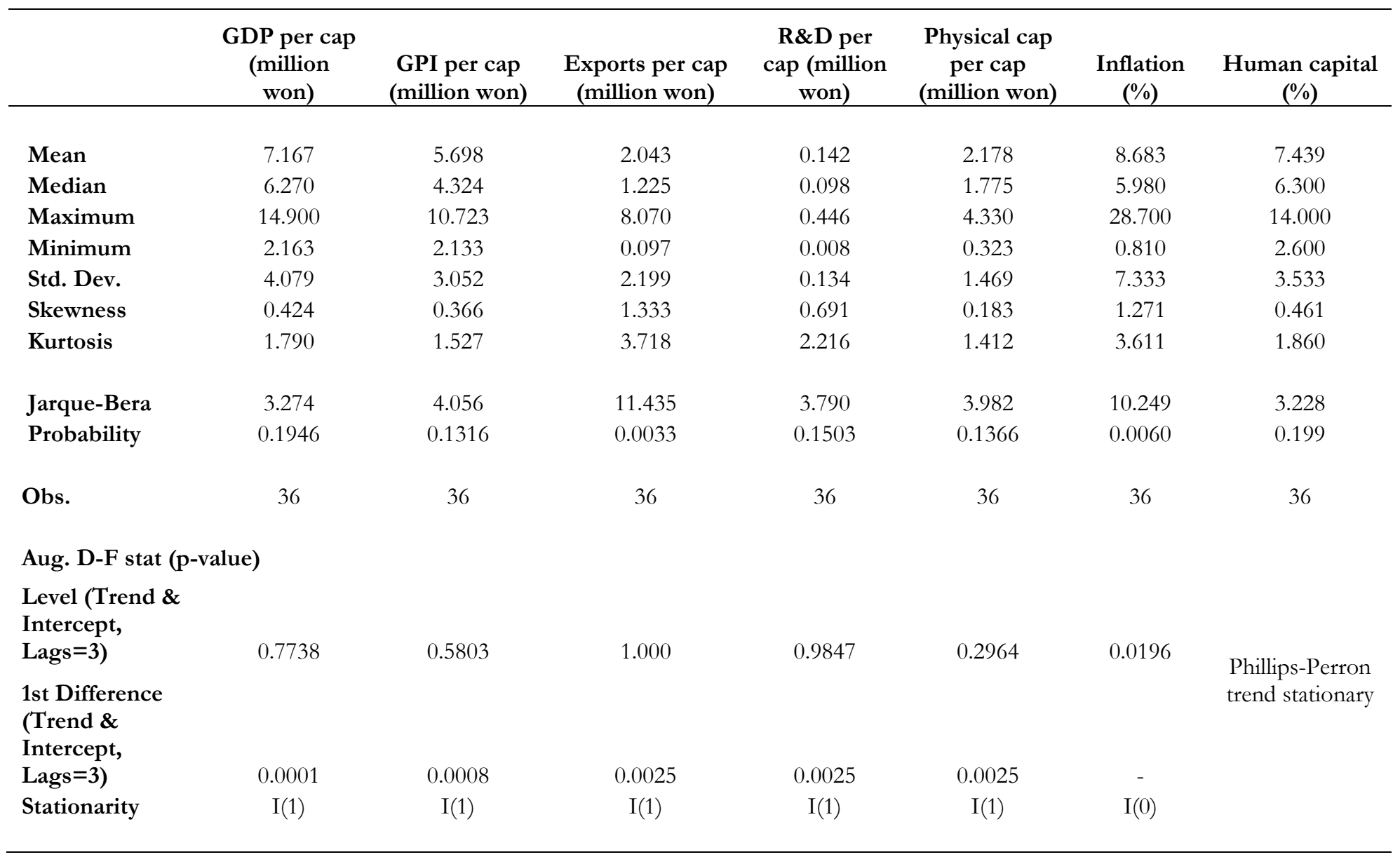

Note: The human capital variable is proxied by the number of South Koreans who have completed post-secondary education as a percentage of the population aged 15 years and over.

Figure 1: South Korea's GDP versus GPI 


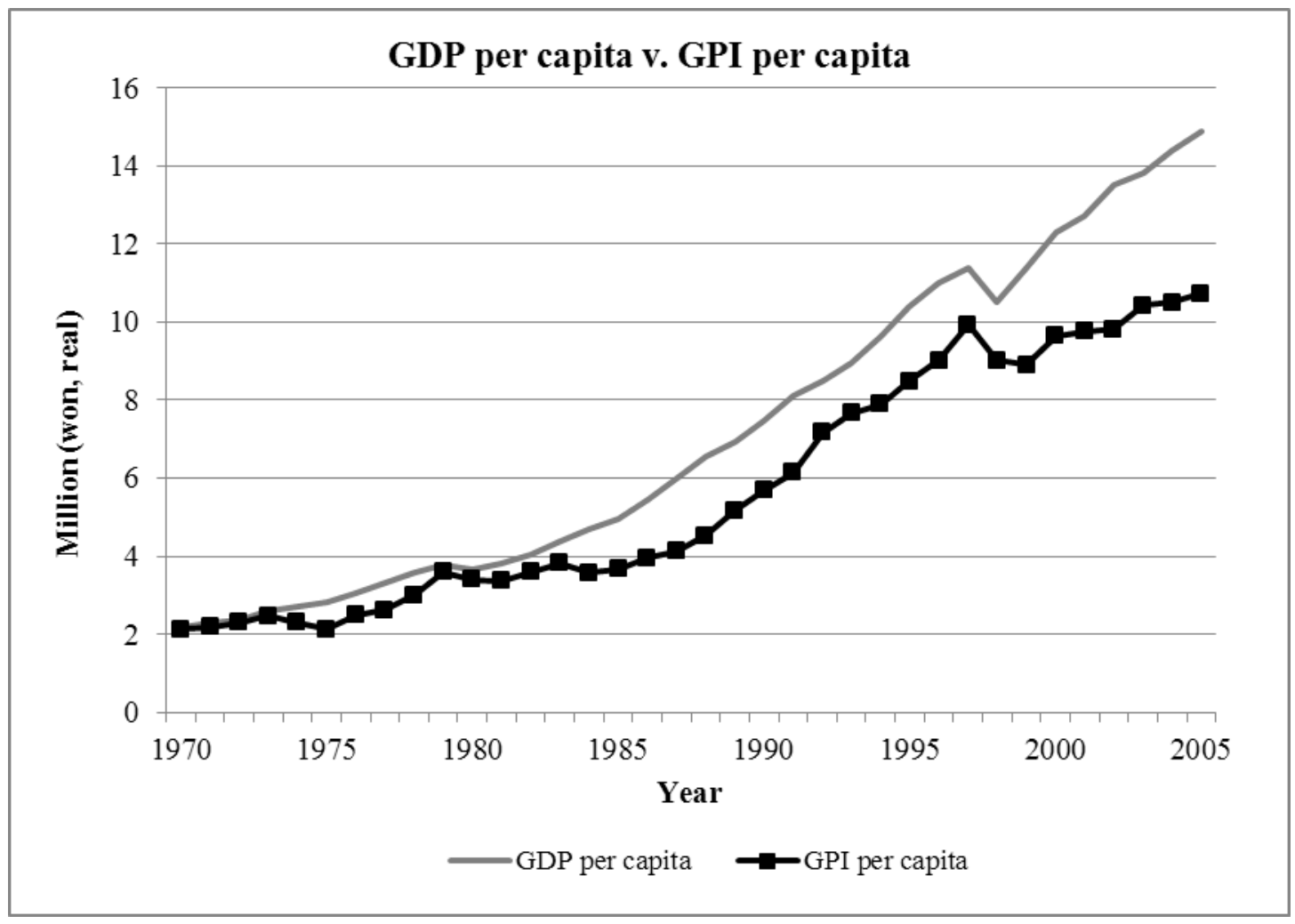


Table 5: GDP model results for South Korea

\begin{tabular}{|c|c|c|c|c|}
\hline & Base model & Inflation squared & $\begin{array}{c}\text { Dummy }= \\
1998\end{array}$ & Final model \\
\hline & Coefficient & Coefficient & Coefficient & Coefficient \\
\hline \multirow[t]{2}{*}{ Intercept } & 0.2259 & 0.2933 & 0.2710 & 0.2220 \\
\hline & $(0.0001)^{* * *}$ & $(0.0003)^{* * *}$ & $(0.0001)^{* * *}$ & $(0.0001)^{* * *}$ \\
\hline \multirow[t]{2}{*}{ Exports } & 0.1519 & 0.1435 & 0.2013 & 0.1619 \\
\hline & $(0.1382)$ & $(0.1212)$ & $(0.0405)^{* *}$ & $(0.0822)^{*}$ \\
\hline \multirow[t]{2}{*}{ Research } & 5.5484 & 5.0517 & 3.9316 & 5.5961 \\
\hline & $(0.0219)^{* *}$ & $(0.0329)^{* *}$ & $(0.1346)$ & $(0.0186)^{* *}$ \\
\hline \multirow[t]{2}{*}{ Physical capital } & 0.8761 & 0.8854 & 0.7526 & 0.8669 \\
\hline & $(0.000)^{* * *}$ & $(0.000)^{* * *}$ & $(0.000)^{* * *}$ & $(0.000)^{* * *}$ \\
\hline \multirow[t]{2}{*}{ Inflation } & -0.0077 & -0.0229 & -0.0093 & -0.0075 \\
\hline & $(0.0315)^{* *}$ & $(0.0639) *$ & $(0.0125)^{* *}$ & $(0.0283)^{* *}$ \\
\hline Human capital & $\begin{array}{c}0.0086 \\
(0.8019)\end{array}$ & & & \\
\hline Inflation squared & & $\begin{array}{c}0.0005 \\
(0.1893)\end{array}$ & & \\
\hline Dummy $=1998$ & & & $\begin{array}{c}-0.302272 \\
(0.1977)\end{array}$ & \\
\hline R-squared & 0.8821 & 0.8888 & 0.8885 & 0.8818 \\
\hline Adjusted R-squared & 0.8618 & 0.8696 & 0.8693 & 0.8661 \\
\hline S.E. of regression & 0.1214 & 0.1180 & 0.1181 & 0.1195 \\
\hline F-statistic & 43.390 & 46.340 & 46.223 & 55.967 \\
\hline P-value (F-statistic) & $(0.000)^{* * *}$ & $(0.000)^{* * *}$ & $(0.000)^{* * *}$ & $(0.000)^{* * *}$ \\
\hline Akaike info criterion & -1.2239 & -1.2821 & -1.2799 & -1.2788 \\
\hline Schwarz criterion & -0.9572 & -1.0155 & -1.0132 & -1.0566 \\
\hline Hannan-Quinn criter. & -1.1318 & -1.1901 & -1.1878 & -1.2021 \\
\hline Durbin-Watson stat & 2.2109 & 2.3193 & 1.8780 & 2.2154 \\
\hline \multicolumn{5}{|c|}{ Heteroskedasticity test (White) } \\
\hline F-statistic & 4.336 & 5.104 & 4.033 & 5.475 \\
\hline P-value (F-statistic) & $0.0046^{* * *}$ & $0.0018^{* * *}$ & $0.0067^{* * *}$ & $0.0020^{* * *}$ \\
\hline \multicolumn{5}{|c|}{ Autocorrelation test (Q-statistics) } \\
\hline 1 lag (p-value) & 0.4910 & 0.3010 & 0.7370 & 0.4850 \\
\hline 2 lags (p-value) & 0.7720 & 0.5460 & 0.9160 & 0.7670 \\
\hline 3 lags ( $p$-value) & 0.9140 & 0.7460 & 0.9800 & 0.9120 \\
\hline 4 lags (p-value) & 0.3210 & 0.3640 & 0.6010 & 0.3170 \\
\hline \multicolumn{5}{|c|}{ Normality test (Jarque-Bera) } \\
\hline Statistic & 5.627 & 2.010 & 4.8270 & 7.292 \\
\hline P-value & $0.0600 *$ & 0.3660 & $0.0895^{*}$ & $0.0261 * *$ \\
\hline
\end{tabular}

Notes:

Values are in millions (won)

- $\quad$ Values in brackets are p-values: * denotes statistical significance at the $10 \%$ level; ** denotes statistical significance at the $5 \%$ level; and $* * *$ denotes statistical significance at the $1 \%$ level.

- The human capital variable is detrended and is proxied by the number of South Koreans who have completed post-secondary education as a percentage of the population aged 15 years and over.

- To correct the t-statistics for heteroskedasticity in each of the models, the Newey-West adjustment was applied.

Table 6: GPI model results for South Korea 
Table 7: GPI error correction model

\begin{tabular}{lclc}
\hline Long-Run Equation & \multicolumn{3}{c}{ Short-Run Equation } \\
\hline & Coefficient & & Coefficient \\
\hline Intercept & 1.6043 & Intercept & 0.1674 \\
& $(0.000)^{* * *}$ & & $(0.1033)$ \\
Exports & 0.2552 & $\square$ Exports & 0.0842 \\
& $(0.2446)$ & & $(0.6583)$ \\
Research & 3.6515 & $\square$ Research & 4.6650 \\
& $(0.5661)$ & & $0.3270)$ \\
Physical capital & 1.4028 & $\square$ Physical capital & 0.4966 \\
& $(0.000)^{* * *}$ & & $(0.0429)^{* *}$ \\
& & Inflation & -0.0055 \\
& & & $(0.4204)$ \\
& & ECV & -0.5204 \\
& & & $(0.0002)^{* * *}$ \\
R-squared & 0.9855 & R-squared & 0.6261 \\
Adjusted R-squared & 0.9842 & Adjusted R-squared & 0.5616 \\
S.E. of regression & 0.3842 & S.E. of regression & 0.2452 \\
F-statistic & 726.640 & F-statistic & 9.7125 \\
P-value (F-statistic) & $0.000^{* * *}$ & P-value (F-statistic) & $0.000 * * *$ \\
Akaike info criterion & 1.0293 & Akaike info criterion & 0.1812 \\
Schwarz criterion & 1.2052 & Schwarz criterion & 0.4479 \\
Hannan-Quinn criter. & 1.0907 & Hannan-Quinn criter. & 0.2733 \\
Durbin-Watson stat & 0.8363 & Durbin-Watson stat & 1.6818 \\
\hline
\end{tabular}

Notes:

- Values are in millions (won)

- Values in brackets are p-values: * denotes statistical significance at the $10 \%$ level; $* *$ denotes statistical significance at the $5 \%$ level; and $* * *$ denotes statistical significance at the $1 \%$ level.

- $\mathrm{ECV}=$ error correction variable. 